\title{
Evaluation of marketing methods used to promote extension programs as perceived by Master Gardeners in West Virginia
}

\author{
Tiffany Dale Rexroad \\ West Virginia University
}

Follow this and additional works at: https://researchrepository.wvu.edu/etd

\section{Recommended Citation}

Rexroad, Tiffany Dale, "Evaluation of marketing methods used to promote extension programs as perceived by Master Gardeners in West Virginia" (2002). Graduate Theses, Dissertations, and Problem Reports. 1487.

https://researchrepository.wvu.edu/etd/1487

This Thesis is protected by copyright and/or related rights. It has been brought to you by the The Research Repository @ WVU with permission from the rights-holder(s). You are free to use this Thesis in any way that is permitted by the copyright and related rights legislation that applies to your use. For other uses you must obtain permission from the rights-holder(s) directly, unless additional rights are indicated by a Creative Commons license in the record and/ or on the work itself. This Thesis has been accepted for inclusion in WVU Graduate Theses, Dissertations, and Problem Reports collection by an authorized administrator of The Research Repository @ WVU. For more information, please contact researchrepository@mail.wvu.edu. 

Evaluation of Marketing Methods Used to Promote Extension Programs as Perceived
by Master Gardeners in West Virginia

\title{
Tiffany Dale Rexroad
}

Thesis submitted to the Davis College of Agriculture, Forestry, and Consumer Sciences at West Virginia University in partial fulfillment of the requirements for the degree of

\section{Master of Science}

in

Agricultural and Environmental Education

Layle D. Lawrence, Ph.D., Chair Stacy A. Gartin, Ph.D. Harry N. Boone, Jr., Ph.D.

Division of Resource Management

\author{
Morgantown, West Virginia \\ 2002
}

Keywords: Agriculture, Extension, Master Gardeners 


\begin{abstract}
Evaluation of Marketing Methods Used to Promote Extension Programs as Perceived by Master Gardeners in West Virginia
\end{abstract}

Tiffany Dale Rexroad

The purpose of this study was to provide information to Extension professionals regarding effectiveness of the methods of advertising and marketing that may help them choose methods to encourage participation in Extension programs. The objective was to evaluate effectiveness of methods of promoting the WVU-ES based on experiences of current adult Master Gardeners in WV.

A major finding of the study was that for WV Master Gardeners referrals from friends is an effective method of creating awareness of Extension programs. Newspaper articles were the most effective mass media method. The preferred method of receiving Extension information was via Extension newsletter followed by newspaper articles. Those Master Gardeners with Internet and e-mail have a greater preference for those channels, while urban respondents had a greater preference for television. 


\section{AKNOWLEGEMENTS}

I would like to thank all the Master Gardeners who participated in the survey. Without their help, this study would not have been successfully completed.

To Dr. Gartin, thank you for the advice and encouragement both academically and otherwise. You listened and put up with my shenanigans, pet projects and vast ideas, and helped me through the rough times. Dr. Lawrence, thank you for your patience and for keeping me on track. Thank you Dr. Boone. I learned more about statistics in a few hours with you than in an entire semester of Statistics 101.

Bill Shockey, thank you for your insight into Extension and for being a terrific supervisor. To the rest of the Extension Gang (Kay, Diana, Tracy, and Gloria), it was a privilege to work with you. 


\section{TABLE OF CONTENTS}

TITLE PAGE

ABSTRACT

ii

ACKNOWLEDGEMENTS

iii

TABLE OF CONTENTS

iv

LIST OF TABLES

vii

CHAPTER I

INTRODUCTION

Purpose and Objectives

Research Questions

Limitations of the Study

\section{CHAPTER II}

REVIEW OF THE LITERATURE

Importance of Promoting Extension

Utilization of Mass Media

Awareness and Visibility

Demographic Influences

Summary of the Literature

CHAPTER III

METHODOLOGY

Purpose and Objectives

Research Questions

Research Design 
Population and Sample

Instrumentation

Data Collection

Analysis of the Data

\section{CHAPTER IV}

FINDINGS

Purpose and Objectives

Research Questions

Analysis

Instrument Validity and Reliability

Demographics of Sample Group

Awareness of Extension Programming

Methods - First Awareness of Extension Programming

First Experience with Extension

Encouragement of Participation in Other Extension Programs

Preferences of Methods

Internet and E-mail Access

Effects of Demographic Variables on Preferences

\section{CHAPTER V}

SUMMARY, CONCLUSIONS, AND RECOMMENDATIONS

Purpose and Objectives

Research Questions

Demographics 
$\begin{array}{ll}\text { Awareness of Extension Programming } & 38\end{array}$

Methods - First Awareness of the Master Gardener Program 38

Methods - First Awareness of Other Extension Programs 39

Encouragement to Participate in Other Extension Programs 40

$\begin{array}{ll}\text { Preferences of Methods } & 40\end{array}$

Preferences of Methods by Internet and E-mail Access 41

Effects of Demographics on Preferences of Methods 41

Recommendations for Extension Professionals 42

$\begin{array}{lr}\text { REFERENCES } & 44\end{array}$

$\begin{array}{lr}\text { APPENDICES } & 46\end{array}$

$\begin{array}{lr}\text { APPENDIX A: Survey Instrument } & 47\end{array}$

APPENDIX B: Letter to Selected Master Gardeners 52

APPENDIX C: Follow Up Letter to Master Gardeners 54

$\begin{array}{ll}\text { VITA } & 56\end{array}$ 


\section{LIST OF TABLES}

Table 1: Demographic Characteristics

Table 2: Frequency and Percentage of Awareness of Extension Programming

Table 3: Frequency and Percentage of Methods by which Participants Became Aware of Extension Programs

Table 4: Frequency and Percentage of Master Gardeners as First Extension Experience

Table 5: Frequency and Percentage of Other Extension Programs as First Extension Experience

Table 6: Frequency and Percentage of Encouragement of Participation in Other Extension Programs

Table 7: Frequency and Percentage of Preferences of Methods

Table 8: Frequency and Percentage of Respondents' Website Use and E-mail Activity

Table 9: Comparison of Preferred Methods for Receiving Extension Information by Internet and E-mail Access

Table 10: Comparison of Preferred Methods by Area

Table 11: Comparison of Preferred Methods by Age

Table 12: Comparison of Preferred Methods by Education Level

Table 13: Comparison of Preferred Methods by Income

Table 14: Comparison of Preferred Methods by Gender 


\section{CHAPTER I}

\section{INTRODUCTION}

The Cooperative State Research, Education, and Extension Service (CSREES) is a non-formal educational branch of the land grant university that extends into each county in the United States and addresses educational needs of the populace. Extension includes more than 130 colleges of agriculture, 59 agricultural experiment stations, and 57 cooperative Extension services in each state, territory, and the District of Columbia (Cooperative State Research, Education, and Extension Service, 2001). In cooperation with our partners and customers, CSREES provides the focus to advance a global system of research, Extension and higher education in the food and agricultural sciences and related environmental and human sciences to benefit people, communities, and the Nation. The CSREES mission emphasizes partnerships with the public and private sectors to maximize the effectiveness of limited resources. CSREES programs increase and provide access to scientific knowledge; strengthen the capabilities of land-grant and other institutions in research, Extension and higher education; increase access to and use of improved communication and network systems; and promote informed decision making by producers, families, communities, and other customers. (CSREES, 2001, n.p.)

Since passage of the Smith-Lever Act of 1914, Extension's focus has been on educational programs for rural clientele in each state. However, as the nation's population has become increasingly non-rural, Extension has shifted its focus to include 
programs directed at needs of urban and suburban clientele. The CSREES considers itself a $21^{\text {st }}$ century change agent directed at national priorities (CSREES, 2001).

The heart of the CSREES results-oriented vision is to improve economic, environmental, and social conditions in the United States and globally. These conditions include improved agricultural and other economic enterprises; safer, cleaner water, food, and air; enhanced stewardship and management of natural resources; healthier, more responsible and more productive individuals, families and communities; and a stable, secure, diverse and affordable national food supply. (CSREES, 2001, n.p.)

In West Virginia, the Extension Service implements programs in Agriculture and Natural Resources Development; 4-H Youth, Family, and Adult Development; and Community and Workforce Development. The West Virginia University Extension Service (WVU-ES) is as follows:

The mission of the WVU Extension Service is to form learning partnerships with the people of West Virginia to enable them to improve their lives and communities. To these partnerships we bring useful research- and experiencebased knowledge that facilitates critical thinking and skill development. (West Virginia University Extension Service, 2000, n.p.)

Because the Extension Service is a non-formal educational system, participation in Extension programs is predominantly voluntary. Therefore, the problem arises on how to effectively promote awareness of the Extension Service and its programs. If potential clientele do not know of the Extension Service or a particular program, then 
they are not likely to participate in the program or programs, and the Extension Service cannot fulfill its mission or justify its continued existence.

This is especially true of non-traditional programs like the Master Gardeners program. The Master Gardeners program is a horticultural training and volunteer leader organization that operates under the guidance of the individual state Extension Service. This program allows gardeners to enhance their horticultural skills and then share their education and experience with others through community service (West Virginia University Extension Service, 2001).

While the Extension Service is a government-funded agency that, in theory, serves every person in the nation, a national study by Warner, Christenson, Dilman, \& Salant (1996) found that only 45\% have heard of Extension. Many Extension professionals have cited a lack of visibility and marketing of the Extension Service as a primary barrier in reaching the populace (Culp, 1997). Currently, Extension relies heavily on dissemination of information to clientele listed on mailing lists, usually through fliers or newsletters mailed directly to the client. Clientele are then expected to relay this information to potential clientele with whom they have contact. Also public service announcements for particular Extension programs can be seen or heard through local newspapers or radio stations. Recently, Extension professionals have developed and adapted mass media methods normally employed by the private sector, such as television and/or the Internet, for the promotion of the Extension Service.

There are many ways in which the Extension professional can communicate an awareness of Extension and its programs to the public. First, there are the commercial mass media methods, which include advertisements on radio, in newspapers, or on TV, 
press releases, fliers, and newsletters (Lionberger \& Gwin, 1982). Newspaper articles or columns and radio or TV broadcasts delivered by an agent or the Extension Service are also included in mass media methods. West Virginia also has an extensive website to promote Extension and disseminate information to clientele.

As opposed to mass media methods, clientele can find out about Extension programs through word of mouth from people with whom they come in contact. Word of mouth includes referrals from other public and private agencies, such as the Farm Service Agency, U.S. Forest Service, or Farm Bureau or referrals from privately owned businesses. It also includes referrals from a relative or peer who has participated in Extension programs previously or who has heard of the Extension Service from another source.

With the many methods to promote the Extension Service, it can become difficult and confusing for the agent to choose appropriate methods of promoting awareness of Extension that encourages participation in programs. Furthermore, there has been a great deal of research published on the lack of awareness of Extension, but little has been done to determine if this lack of awareness is due to the methods of marketing selected by Extension professionals.

\section{Purpose and Objectives}

The major purpose of this study was to provide information to Extension agents and administrators regarding effectiveness of the various methods of advertising and marketing that may help them choose methods that will encourage participation in Extension programs. 
The primary objective of this study was to evaluate effectiveness of the various methods of promoting WVU-ES programs based on experiences of current adult Master Gardeners in West Virginia.

\section{$\underline{\text { Research Questions }}$}

The research questions that directed this study were:

1. How did Master Gardeners first become aware of Extension programs?

2. Which marketing methods are most effective at promoting awareness of other Extension programs among Master Gardeners?

3. Does participation in the Master Gardener Program promote interest in other Extension Programs?

4. What are the preferences of Master Gardeners in receiving Extension information?

5. Does the availability of Internet related communication channels affect the preferences of certain marketing methods?

6. What is the relationship between selected demographic variables; rural/ suburban/ urban, age, education, gender and economic status, and preferences of marketing methods?

\section{Limitations of the Study}

The study was limited to current adult Master Gardeners in West Virginia as listed in the 2001 State Master Gardener Directory. It did not include other clientele or youths. 


\section{CHAPTER II}

REVIEW OF THE LITERATURE

\section{Importance of Promoting Extension}

The growing conviction among Extension professionals has been that to survive Extension needs to more efficiently market itself to the public, government, and other key stakeholders. Extension's first basic problem is one of lack of general awareness of Extension. Jenkins (1993) stated in his article that the reason Extension seems to have an unfavorable image is that Extension has "no image at all." The Extension Service's image is based on two factors, a client's awareness and favorability of Extension. Those clients who have previously been involved with Extension programs and services tend to have a positive opinion of the Extension Service. The problem remains that many are not aware that the Extension Service exists or are unfamiliar with its programs. Even when the general public is aware of Extension they do not understand its mission (Adkins, 1981).

In an effort to rectify the lack of awareness of Extension, many working in Extension have suggested that they adapt mass media marketing strategies used by the private sector to promote Extension. Weerakkody (1986) identified major problems for Extension and found that agents claim that (1) farmers/ ranchers are not aware of what is available from Extension and (2) there are too few agents in the field. He recommended the use of mass media methods to counter these issues (p. 59). Lionberger and Gwin (1982) used the individual adoption process to justify the use of mass media. The first two stages of the adoption process are awareness and interest, both of which are best accomplished through the use of mass media channels. 
On the other hand, there exists among many Extension professionals a general attitude against marketing of Extension. Many believe that "if we do good work... our efforts will be noticed and rewarded" (Jenkins, 1993, n.p.). These agents feel that satisfied clientele would spread a favorable image of Extension to others.

\section{$\underline{\text { Utilization of Mass Media }}$}

The nature of mass media allows communication with large groups of people not seen and generally not known. Lionberger \& Gwin (1982) pointed out that mass media also has the ability to entertain as well as inform, which creates the potential for greater impact and awareness. "The two [education and entertainment] are not incompatible" (p. 82). Therefore mass media channels will have important long-term effects. Mass media will get people to talk and discuss the Extension service, multiplying the impact of word-of-mouth channels.

Hogan (1994) demonstrated the validity of marketing Extension through the initiation of a public relations and marketing program at the Carroll County office of the Ohio State University Extension. His study outlined the methods and impacts of this program. The primary goals of the program were to (1) increase public awareness of Extension, (2) increase government awareness of Extension and the impacts of local Extension programs, (3) to increase financial support for Extension programs, and (4) to increase the size and scope of the county Extension program. The Carroll County Extension distributed a yearly "Report to the People" newsletter to current clientele through direct mail and also distributed it to people not on the mailing lists through libraries, grocery stores, and other channels. A quarterly report was also developed for county commissioners, legislators, and Extension Advisory Council members. Included 
in the public relations program were tours demonstrating Extension's accomplishments, special newspaper supplements, displays at community events, and a town meeting to discuss and determine the peoples' needs. The impact of this program was measured by increases in county funding and in the size and scope of the Carroll County programming. County funding increased $116 \%$, county staff increased from 3.5 to 5.8 people and the number of programs offered locally increased. Carroll County Extension was able to meet their objectives through the use of a variety of mass marketing techniques.

Many agents and specialists in Extension have promoted specific programs using one or two mass advertising methods with a great deal of success. Specialists from the New Jersey Extension prepared articles monthly for the newspaper consisting of a "case study" of the finances of a particular rural family as a way to disseminate financial information and evoke interest in Extension financial information. Within one week after the first article appeared, the office received several requests for financial bulletins and financial planning questionnaires (O'Neill, 1987).

In a study investigating information sources used by farmers, Najafi (1975) reported that printed sources such as magazines and newspapers along with one-onone contact with their agents rated highly with farmers, with radio rating slightly less, and TV the least useful for the farmer. Najafi states, "printed materials dealing with agriculture have the potential of creating interest among farmers" (pp. 49-50).

Dennis, Lee, and Jenson (1995) implemented a TV program for community access cable to disseminate information for a parenting education program for the Utah State University Extension. The program was promoted through the PTA. A follow-up 
survey was mailed to cable recipients with their monthly bills. While there was a response rate of only $4.5 \%$ to the survey, $18 \%$ of the respondents, watched one or more of the programs, $86 \%$ felt the programs provided good information and were a good use of tax dollars, and $75 \%$ said they would have watched had they known about the programs. Half of those who viewed the programs had found out through their local PTA and $44 \%$ had stopped on the program while flipping through the channels. New measures to promote the programs have been introduced including quarterly newsletters distributed through the PTA and Public Service Announcements over the radio.

Awareness and Visibility

A study by Warner, Christenson, Dillman, and Salant (1996) showed that the changes that had taken place in Extension, including more visibility of individual programs and an increased emphasis on marketing, had not significantly changed awareness and perception of the Extension Service. A survey done in 1995 was compared to the same survey conducted in 1982. In the 13-year interval, awareness of the Extension Service increased only slightly from $40 \%$ to $45 \%$ of the respondents. The respondents were asked if they knew of Extension programs in the different areas of the Extension Service. Out of these the 4-H program had the greatest awareness level in 1995 , with $69 \%$ of the respondents being aware of $4-\mathrm{H}$. This is down from an awareness level of $77 \%$ in 1982 . Approximately half of the people knew about Extension programs in the home economics and agriculture areas, and $38 \%$ were aware of community development. Awareness of both agriculture and community 
development decreased from 1982 levels, while home economics increased from 45\% to $51 \%$ in the 13 -year interval.

The real question though is whether increased visibility and marketing lead to increased participation. Participants were asked if they or a family member had ever used the Extension Service before and if they had participated in an Extension program in the past year. In both 1982 and 1995, the rate of respondents who had ever participated in an Extension program was 26\%. More significantly though, the rate of participation among the respondents within the past year had dropped from $12 \%$ in 1982 to $8 \%$ in 1995. Annual use of Extension registered a decline even with an increased emphasis on visibility and marketing (Warner, et al., 1996).

\section{Demographic Influences}

Meadowbrook and Fletcher (1988) said that to effectively market Extension, Extension professionals need to know the characteristics of current clientele compared to potential clientele. Interview surveys covering clientele demographics, versus total population demographics in Marion County, Oregon were conducted by telephone. Two samples were drawn; one from mailing lists and another from contacts who were not on mailing lists. Of all individuals contacted, only $3 \%$ would not respond.

Demographically, a vast majority of Marion County's current clientele were 60 years or older, with only $6 \%$ under the age of 30 . They also had a higher education level than the majority of Marion County residents. Clients in agriculture related professions earned a higher gross income than did than the average for agriculturists in the county.

Of the contacts, $90 \%$ knew about the wide variety of topics Extension has to offer. Fiftyfive percent of all clients said they heard about Extension from a friend or relative. Of 
the suggestions on how to better the Extension Service, the need to increase public relations and make more people aware of Extension was the most common. The demographics of clientele can be used to inversely infer the characteristics of those who are not currently Extension clientele (Meadowbrook \& Fletcher, 1998). This may also be true of marketing strategies for Extension. Those methods that work for present, traditional clientele may not work for the potential clientele whom Extension has not been able to reach.

\section{Summary of the Literature}

Less than half of the potential clientele base knows of the existence of the Extension Service, and of those who do participation in individual programs has been decreasing (Warner, et al., 1996). Specific programs suffer for lack of promotion, and even clientele point out that Extension needs to become more visible (Culp, 1997; Meadowbrook \& Fletcher, 1998). There is a great deal of conflict as to whether or not mass media methods are more effective than word of mouth (Jenkins 1993; Warner, et al, 1996), although many Extension offices have implemented marketing plans which have been successful in promoting the Extension Service (Hogan 1994; O'Neill, 1987; Dennis, Lee, \& Jenson, 1995). An understanding of clientele demographics is important to understanding how various groups of clientele will respond to marketing methods (Meadowbrook \& Fletcher, 1998). 


\section{CHAPTER III}

\section{METHODOLOGY}

\section{Purpose and Objectives}

The major purpose of this study was to provide information to Extension agents and administrators regarding effectiveness of the various methods of advertising and marketing that may help them choose methods that will encourage participation in Extension programs.

The primary objective of this study was to evaluate effectiveness of the various methods of promoting West Virginia University Extension Service (WVU-ES) programs based on the experiences of current adult Master Gardeners in West Virginia.

\section{$\underline{\text { Research Questions }}$}

The research questions that directed this study were:

1. How did Master Gardeners first become aware of Extension programs?

2. Which marketing methods are most effective at promoting awareness of other Extension programs among Master Gardeners?

3. Does participation in the Master Gardener Program promote interest in other Extension Programs?

4. What are the preferences of Master Gardeners in receiving Extension information?

5. Does the availability of Internet related communication channels affect the preferences of certain marketing methods? 
6. What is the relationship between selected demographic variables; rural/ suburban/ urban, age, education, gender and economic status, and preferences of marketing methods?

\section{$\underline{\text { Research Design }}$}

A descriptive survey research method was used to collect data from the target population. "Descriptive research is not generally directed toward hypothesis testing. The aim is to "describe, 'what exists' with respect to variables or conditions in a situation" (Ary, 1990, p. 381). It is the aim of this research to discover "what exists" among those who participate in the Master Gardener Program.

"Descriptive surveys focus on determining the status of a defined population with respect to certain variables. They basically inquire into the status quo; they attempt to measure what exists without questioning why it exists" (Ary, 1990, p. 407).

Population and Sample

The target population for this study was all 819 members of the Master Gardeners Program in West Virginia as listed in the 2001 State Master Gardener Directory. The accessible population was a random sample of 130 members from the target population as determined by Cohen's (1998) tables using an alpha level of .05, a power of .90 , and a .40 effect size. The power of .90 was selected due to the less rigorous nature of this study. The sample was selected using the Statistical Package for the Social Sciences (SPSS) for Windows.

Instrumentation

The survey was mailed to the selected sample of Master Gardeners in West Virginia. The instrument was designed by the researcher from an evaluation of literature 
on the different promotional methods available to Extension (see Appendix A). As this was a new instrument of the researcher's design, faculty members in Agricultural and Environmental Education and WVU-ES at West Virginia University examined the survey to establish content and face validity. Instrument reliability was determined from an analysis of the data from the sample population using Cronbach's alpha.

The participants responded to questions identifying those marketing methods that have had the most impact on their decision to first utilize Extension programs and those marketing methods by which they prefer to receive Extension information. Also questions pertaining to demographic data and access to certain marketing channels were asked to determine the influence, if any, these factors have on the effectiveness of a method.

\section{Data Collection}

A survey and cover letter (see Appendix B) was mailed to a sample $(N=130)$ of current adult Master Gardeners in West Virginia along with a self addressed stamped envelope for the return of the survey. Follow up letters (see Appendix $C$ ) with a new survey in a different color were sent according to the methods recommended by Dillman (1978).

\section{Analysis of the Data}

This study sought to rate individual promotional methods according to effectiveness at encouraging first time participation and continued participation in the Extension programs. Data from the survey were entered into Excel tables and then analyzed using SPSS at West Virginia University. Descriptive analyses including frequencies, percentages, and means were performed and presented in narrative and 
tabular form, as well as ANOVA and Cohen's $f$ coefficients to compare differences in preferences between groups. 


\section{CHAPTER IV}

\section{FINDINGS}

\section{$\underline{\text { Purpose and Objectives }}$}

The major purpose of this study was to provide information to Extension agents and administrators regarding effectiveness of the various methods of advertising and marketing that may help them choose methods that will encourage participation in Extension programs.

The primary objective of this study was to evaluate the effectiveness of the various methods of promoting West Virginia University Extension Service (WVU-ES) programs based on the experiences of current adult Master Gardeners in West Virginia.

\section{$\underline{\text { Research Questions }}$}

The research questions that directed this study were:

1. How did Master Gardeners first become aware of Extension programs?

2. Which marketing methods are most effective at promoting awareness of other Extension programs among Master Gardeners?

3. Does participation in the Master Gardener Program promote interest in other Extension Programs?

4. What are the preferences of Master Gardeners in receiving Extension information?

5. Does the availability of Internet related communication channels affect the preferences of certain marketing methods? 
6. What is the relationship between selected demographic variables; rural/ suburban/ urban, age, education, gender and economic status, and preferences of marketing methods?

$\underline{\text { Analysis }}$

Responses of West Virginia Master Gardeners are summarized and presented in the following areas: demographics of the sample group; awareness of Extension programming, frequency and percentage of methods by which participants became aware of Extension programs, first experience with Extension, encouragement of participation in other Extension programs, preferences of methods for receiving Extension information, access to Internet and e-mail, and effects of demographic variables on preferences.

Data were analyzed at West Virginia University using Statistical Package for the Social Sciences for Windows (SPSS). Data were analyzed using frequencies, percentages, means, ANOVA and Cohen's $f$ coefficients. $\underline{\text { Instrument Validity and Reliability }}$

The instrument was designed by the researcher from an evaluation of literature on the different promotional methods available to Extension (see Appendix A). Faculty members in Agricultural and Environmental Education and WVU-ES at West Virginia University reviewed the survey to establish content and face validity.

Since the instrument was not pilot tested, reliability was based on an analysis of data from the sample population. The Cronbach's alpha reliability coefficient for questions 1 through 6 was .72 , while the reliability for question 10 was .91 . 


\section{Demographics of the Sample Group}

The target population for this study consisted of all 819 members of the Master Gardeners Program in West Virginia listed in the 2001 State Master Gardeners Directory. The accessible population was a random sample of 130 members from the target population. Fifteen "return to senders" were received reducing the effective sample size to 115 . To prevent frame error, the most recent State Master Gardeners Directory was used for sample selection. The participants were asked their area (rural or urban/suburban), age range, education level, income, and gender.

Information was received from 81 West Virginia Master Gardeners for a response rate of $62.3 \%$, as noted in Table 1. Analyses of variance were used to compare the responses of early and late respondents. There were no significant differences found; therefore, generalizations made include the entire population of the study. Of the respondents, $43(54.4 \%)$ indicated they were from a rural area, while $36(45.6 \%)$ responded as being from an urban or suburban area. In the age group category, 34 $(42 \%)$ of the respondents were in the 50-59 age group, with $17(21 \%)$ and $16(19.8 \%)$ in the 60-69 and 40-49 age groups, respectively. When asked their highest degree earned, 27 (34.2\%) of the respondents indicated a high school diploma or GED, 19 (24.1\%) held a bachelor degree, and $23(29.1 \%)$ held a graduate degree. Of the 67 who responded with income data, 19 (28.4\%) indicated they earned $\$ 40,000$ to $\$ 59,999,17$ (25.4\%) earned $\$ 20,000$ to $\$ 39,999$, and 24 (34.3\%) earned $\$ 60,000$ or more. Among the respondents, 58 (73.4\%) were female and 21 (26.6\%) were male. 
Table 1

Demographic Characteristics $(N=81)$

\begin{tabular}{|c|c|c|}
\hline Variable & $n$ & $\%$ \\
\hline \multicolumn{3}{|l|}{ Area } \\
\hline Rural & 43 & 54.4 \\
\hline Urban or Suburban & 36 & 45.6 \\
\hline \multicolumn{3}{|l|}{ Age Group } \\
\hline 30 to 39 & 2 & 2.5 \\
\hline 40 to 49 & 16 & 19.8 \\
\hline 50 to 59 & 34 & 42.0 \\
\hline 60 to 69 & 17 & 21.0 \\
\hline $70+$ & 11 & 13.6 \\
\hline \multicolumn{3}{|l|}{ Highest Education Level } \\
\hline High School Diploma or GED & 27 & 34.2 \\
\hline 2 Year Degree or Technical School & 10 & 12.7 \\
\hline Bachelor's Degree & 19 & 24.1 \\
\hline Graduate Degree & 23 & 29.1 \\
\hline \multicolumn{3}{|l|}{ Income Level } \\
\hline$\$ 0$ to $\$ 19,999$ & 8 & 11.9 \\
\hline$\$ 20,000$ to $\$ 39,999$ & 17 & 25.4 \\
\hline$\$ 40,000$ to $\$ 59,999$ & 19 & 28.4 \\
\hline$\$ 60,000$ to $\$ 79,999$ & 11 & 16.4 \\
\hline$\$ 80,000$ to $\$ 99,999$ & 2 & 3.0 \\
\hline$\$ 100,000+$ & 10 & 14.9 \\
\hline \multicolumn{3}{|l|}{ Gender } \\
\hline Male & 21 & 26.6 \\
\hline Female & 58 & 73.4 \\
\hline
\end{tabular}




\section{Awareness of Extension Programming}

Of the four Extension program areas, $4-\mathrm{H}$ was the most recognizable with $94.9 \%$ of respondents indicating awareness. Agricultural programs follow closely with $92.6 \%$ awareness. Of the respondents, $61.7 \%$ indicated awareness of Community Education and Outreach Service (CEOS) and other home economics programs, and 57.1\% indicated awareness of community development programs, as seen in Table 2. Table 2

Frequency and Percentage of Awareness of Extension Programming ( $N=81)$

\begin{tabular}{lrrrr}
\hline & \multicolumn{2}{c}{ No } & \multicolumn{2}{c}{ Yes } \\
\cline { 2 - 5 } Programs & $n$ & $\%$ & $n$ & $\%$ \\
\hline WVU Extension Agricultural Programs & 6 & 7.4 & 75 & 92.6 \\
WVU-Extension CEOS & 31 & 38.3 & 50 & 61.7 \\
WVU-Extension Community & & & & \\
Development Programs & 33 & 42.9 & 44 & 57.1 \\
WVU-Extension 4-H & 4 & 5.1 & 75 & 94.9 \\
\hline
\end{tabular}

Methods - First Awareness of Extension Programming

Frequency and percentages of responses indicating method by which the respondent first became aware of the Master Gardener program and other Extension programs were examined (see Table 3). Looking at all Extension programs, referrals by friends, relatives, or peers were the most frequently indicated with 31 respondents (38.3\%) for Master Gardeners, 14(18.9\%) for agricultural programs, $11(22 \%)$ for CEOS and home economics programs, 8 (16.7\%) for community development programs, and $26(34.7 \%)$ for $4-\mathrm{H}$. The second most effective method for all programs was newspaper articles, with $23(28.4 \%)$ of the respondents for Master Gardeners, 10 (13.5\%) for agricultural programs, 9 (18\%) for CEOS, 6 (12.5\%) for community development, and $13(17.3 \%)$ for $4-\mathrm{H}$. The second most effective method for programs other than Master 
Gardeners was hearing about it while participating in other Extension programs, with 17 respondents (23\%) in agricultural programs, $10(20 \%)$ in CEOS, $17(35.4 \%)$ in community development, and $12(16 \%)$ of the respondents in $4-\mathrm{H}$.

Looking at specific programs, the most effective methods for Master Gardeners was referrals from friends, 31 (38.3\%), and newspaper articles, 23 (28.4\%). For agricultural programs hearing about it while participating in other programs was the most effective, with 17 (23\%) of the respondents. Referrals from friends, $11(22 \%)$, was most effective for CEOS, and for 4-H as well, 26 (34.7\%). In community development programs, 17 (35.4\%) responded they heard about it while participating in other Extension programs. 
Table 3

Frequency and Percentage of Methods by which Participants Became Aware of Extension Programs ( $N=81)$

\begin{tabular}{|c|c|c|c|c|c|c|c|c|c|c|}
\hline \multirow[b]{2}{*}{ Methods } & \multicolumn{2}{|c|}{$\begin{array}{l}\text { First Awareness } \\
\text { of Master } \\
\text { Gardner Program }\end{array}$} & \multicolumn{2}{|c|}{$\begin{array}{c}\text { Agricultural } \\
\text { Programs }\end{array}$} & \multicolumn{2}{|c|}{ CEOS } & \multicolumn{2}{|c|}{$\begin{array}{c}\text { Community } \\
\text { Development }\end{array}$} & \multicolumn{2}{|c|}{$4-\mathrm{H}$} \\
\hline & $n$ & $\%$ & $n$ & $\%$ & $n$ & $\%$ & $n$ & $\%$ & $n$ & $\%$ \\
\hline Newspaper Advertisement & 8 & 9.9 & 1 & 1.4 & 0 & 0.0 & 0 & 0.0 & 0 & 0.0 \\
\hline Newspaper Article & 23 & 28.4 & 10 & 13.5 & 9 & 18.0 & 6 & 12.5 & 13 & 17.3 \\
\hline Radio Advertisement & 2 & 2.5 & 1 & 1.4 & 0 & 0.0 & 0 & 0.0 & 0 & 0.0 \\
\hline TV Advertisement & 1 & 1.2 & 0 & 0.0 & 0 & 0.0 & 0 & 0.0 & 0 & 0.0 \\
\hline TV Program & 0 & 0.0 & 3 & 4.1 & 0 & 0.0 & 1 & 2.1 & 2 & 2.7 \\
\hline Extension Newsletter & 1 & 1.2 & 2 & 2.7 & 6 & 12.0 & 5 & 10.4 & 2 & 2.7 \\
\hline Extension Internet Site & 0 & 0.0 & 1 & 1.4 & 1 & 2.0 & 0 & 0.0 & 0 & 0.0 \\
\hline Referrals - Friends & 31 & 38.3 & 14 & 18.9 & 11 & 22.0 & 8 & 16.7 & 26 & 34.7 \\
\hline Referrals - Public Agencies & 1 & 1.2 & 4 & 5.4 & 2 & 4.0 & 1 & 2.1 & 4 & 5.3 \\
\hline Referrals - Private Agencies & 1 & 1.2 & 4 & 5.4 & 3 & 6.0 & 1 & 2.1 & 2 & 2.7 \\
\hline Participating in other Extension programs & 1 & 1.2 & 17 & 23.0 & 10 & 20.0 & 17 & 35.4 & 12 & 16.0 \\
\hline Other & 4 & 4.9 & 5 & 6.8 & 2 & 4.0 & 4 & 8.3 & 8 & 10.7 \\
\hline Missing & 8 & 9.9 & 12 & 16.2 & 6 & 12.0 & 5 & 10.4 & 6 & 8.0 \\
\hline
\end{tabular}




\section{First Experience with Extension}

Of the respondents, $40(49.4 \%)$ indicated that the Master Gardeners program was their first experience with Extension, as seen in Table 4. As Table 5 shows, 13 (38.2\%) had experience with 4-H first, 10 (29.4\%) listed agricultural programs as their first experience, 8 (23.5\%) had their first experience with CEOS or other home economics programs, and $3(8.8 \%)$ responded as having community development as their first experience.

Table 4

Frequency and Percentage of Master Gardeners as First Extension Experience ( $N=81)$

\begin{tabular}{lrrrc}
\hline & \multicolumn{2}{c}{ No } & \multicolumn{2}{c}{ Yes } \\
\cline { 2 - 5 } First Experience & $n$ & $\%$ & $n$ & $\%$ \\
\hline Master Gardeners & 41 & 50.6 & 40 & 49.4 \\
\hline
\end{tabular}

Table 5

Frequency and Percentage of Other Extension Programs as First Extension Experience $(N=81)$

\begin{tabular}{lcc}
\hline & \multicolumn{2}{c}{ First Experience } \\
\cline { 2 - 3 } Other Extension Programs & $n$ & $\%$ \\
\hline Agricultural programs & 10 & 29.4 \\
CEOS and other home economics programs & 8 & 23.5 \\
Community and economic development programs & 3 & 8.8 \\
4-H and youth development programs & 13 & 38.2 \\
\hline
\end{tabular}




\section{Encouragement of Participation in Other Extension Programs}

The respondents were nearly divided on whether or not participation in Master

Gardeners had encouraged participation in other programs, as shown in Table 6. Of the respondents, $43(55.1 \%)$ said no.

Table 6

Frequency and Percentage of Encouragement of Participation in Other Extension Programs $(\mathrm{N}=81)$

\begin{tabular}{lrrrc}
\hline & \multicolumn{2}{c}{ No } & \multicolumn{2}{c}{ Yes } \\
\cline { 2 - 4 } Variable & $n$ & $\%$ & $n$ & $\%$ \\
\hline Encourage Participation in Other Programs & 43 & 55.1 & 35 & 44.9 \\
\hline
\end{tabular}

\section{Preferences of Methods}

Preferences of marketing methods are summarized in Table 7 . The individual items were rated on the following scale: $0=$ No Access, $1=$ Greatly Dislike, $2=$ Dislike, 3=Preferred, and 4=Greatly Preferred. The preferred method of receiving Extension information was the Extension Newsletter, with 36 respondents (54.5\%) ranking it as greatly preferred and 19 (28.8\%) ranking it as preferred. The overall mean rating for Extension Newsletters was 3.53. Newspaper articles received 29 (44.6\%) responses in the preferred category and $20(30.8 \%)$ in the greatly preferred category (at a mean rating of 3.22) making it the second most preferred method and the most preferred mass media method. TV programs were third with 21 (33.9\%) of the respondents indicating preference and a mean rating of 3.22. Referrals from friends ranked high with $26(41.9 \%)$ of the respondents and a 3.00 mean rating. While no particular method received a large percentage of respondents indicating that they disliked or greatly disliked that method, many respondents indicated no access to specific channels. 
Among the respondents, $18(30 \%)$ responded having no access to the Internet site, while $18(29 \%)$ indicated having no access to e-mail. For television,18 (30.5\%) said they had no access to Extension TV advertisements, and 17 (27.4\%) responded as having no access to Extension TV programs. Only 8 (12.1\%) indicated they had no access to the Extension newsletter. 
Table 7

Frequency and Percentage of Preferences of Methods $(N=81)$

\begin{tabular}{|c|c|c|c|c|c|c|c|c|c|c|c|}
\hline \multirow[b]{2}{*}{ Methods } & \multicolumn{2}{|c|}{ No Access } & \multicolumn{2}{|c|}{ Greatly Dislike } & \multicolumn{2}{|c|}{ Dislike } & \multicolumn{2}{|c|}{ Preferred } & \multicolumn{2}{|c|}{$\begin{array}{l}\text { Greatly } \\
\text { Preferred }\end{array}$} & \multirow{2}{*}{$\begin{array}{l}\text { Overall } \\
\text { Mean } \\
\text { Rating }\end{array}$} \\
\hline & $n$ & $\%$ & $n$ & $\%$ & $n$ & $\%$ & $n$ & $\%$ & $n$ & $\%$ & \\
\hline Extension Newsletter & 8 & 12.1 & 2 & 3.0 & 1 & 1.5 & 19 & 28.8 & 36 & 54.5 & 3.53 \\
\hline Newspaper Articles & 10 & 15.4 & 2 & 3.1 & 4 & 6.2 & 29 & 44.6 & 20 & 30.8 & 3.22 \\
\hline TV Programs & 17 & 27.4 & 0 & 0.0 & 7 & 11.3 & 21 & 33.9 & 17 & 27.4 & 3.22 \\
\hline Referrals - Friends & 6 & 11.3 & 3 & 5.7 & 6 & 11.3 & 26 & 49.1 & 12 & 22.6 & 3.00 \\
\hline Newspaper Advertisements & 10 & 16.1 & 4 & 6.5 & 8 & 12.9 & 26 & 41.9 & 14 & 22.6 & 2.96 \\
\hline Radio Advertisements & 14 & 23.7 & 4 & 6.8 & 9 & 15.3 & 20 & 33.9 & 12 & 20.3 & 2.89 \\
\hline Extension Internet Site & 18 & 30.0 & 5 & 8.3 & 9 & 15.0 & 14 & 23.3 & 14 & 23.3 & 2.88 \\
\hline Radio Programs & 13 & 22.4 & 3 & 5.2 & 9 & 15.5 & 24 & 41.4 & 9 & 15.5 & 2.87 \\
\hline Electronic Mail & 18 & 29.0 & 7 & 11.3 & 8 & 12.9 & 14 & 22.6 & 15 & 24.2 & 2.84 \\
\hline TV Advertisements & 18 & 30.5 & 5 & 8.5 & 10 & 16.9 & 14 & 23.7 & 12 & 20.3 & 2.80 \\
\hline Referrals - Public Agencies & 6 & 11.1 & 5 & 9.3 & 10 & 18.5 & 27 & 50.0 & 6 & 11.1 & 2.71 \\
\hline Referrals - Private Agencies & 8 & 14.5 & 5 & 9.1 & 11 & 20.0 & 25 & 45.5 & 6 & 10.9 & 2.68 \\
\hline
\end{tabular}

Rating Scale:

$1=$ Greatly Dislike

$2=$ Dislike

$3=$ Preferred

4=Greatly Preferred 
$\underline{\text { Internet and E-mail Access }}$

Frequencies and the analysis of variance were used to determine if significant differences existed in the respondents' preferences and whether or not they had access to the Internet site and e-mail. As indicated in Table 8, 58 (75.3\%) of the respondents indicated they never access the WVU-ES website, while only 23 (29.9\%) responded that they never read e-mail. Of those accessing the website, 15 (19.5\%) said they access it 1 to 3 times per month, $3(3.9 \%)$ responded they access it 4 to 6 times monthly, and only $1(1.3 \%)$ indicated accessing the website 7 to 9 times. Overall, more Master Gardeners responded that they read their e-mail than access the website, with $21(27.3 \%)$ responding they read e-mail 1 to 3 times, $9(11.7 \%)$ indicating 4 to 6,11 (14.3\%) reading e-mail 7 to 9 times, and $13(16.9 \%)$ indicating they read e-mail more than 9 times weekly.

Of those respondents with Internet access, the Extension website was a significantly preferred method as indicated in Table 9. The Internet site received a Cohen's $f$ of 1.75 . There were also significant differences for newspaper articles, extension newsletters, e-mail, and referrals from friends and public agencies. Electronic mail had a large effect size, while newspaper articles, newsletters, and referrals had medium effect sizes.

Among those with access to e-mail, receiving Extension information by e-mail had a Cohen's $f$ of 1.44 indicating a large effect size. Also significant differences were found for newspaper articles, newsletters, the Internet site, and referrals from friends. There were medium effect sizes for articles, newsletters, and referrals and a large effect size for the Internet site. 
Table 8

Frequency and Percentage of Respondents' Website Use and E-mail Activity ( $N=81)$

\begin{tabular}{lrrrr}
\hline & \multicolumn{2}{c}{ Access Website - Monthly } & \multicolumn{2}{c}{ Read E-Mail - Weekly } \\
\cline { 2 - 5 } Frequency & $n$ & $\%$ & $n$ & $\%$ \\
\hline Never & 58 & 75.3 & 23 & 29.9 \\
1 to 3 times & 15 & 19.5 & 21 & 27.3 \\
4 to 6 times & 3 & 3.9 & 9 & 11.7 \\
7 to 9 times & 1 & 1.3 & 11 & 14.3 \\
More than 9 times & 0 & 0.0 & 13 & 16.9 \\
\hline
\end{tabular}


Table 9

Comparison of Preferred Methods for Receiving Extension Information by Internet and E-mail Access ( $N=81)$

\begin{tabular}{|c|c|c|c|c|c|c|c|c|c|c|c|}
\hline \multirow{2}{*}{ Methods } & \multicolumn{5}{|c|}{ Internet } & \multicolumn{5}{|c|}{ E-mail } & \multirow{2}{*}{$\begin{array}{l}\text { Overall } \\
\text { Mean } \\
\text { Rating }\end{array}$} \\
\hline & No & Yes & $F$ & & $\begin{array}{c}\text { Cohen's } \\
f\end{array}$ & No & Yes & $F$ & & $\begin{array}{c}\text { Cohen's } \\
f\end{array}$ & \\
\hline Newspaper Advertisements & 2.23 & 2.67 & 1.585 & & & 2.05 & 2.71 & 3.439 & & & 2.48 \\
\hline Newspaper Articles & 2.22 & 3.08 & 6.923 & * & .33 & 2.22 & 3.00 & 5.314 & * & .29 & 2.72 \\
\hline Radio Advertisements & 1.91 & 2.38 & 1.414 & & & 2.00 & 2.31 & 0.574 & & & 2.20 \\
\hline Radio Programs & 2.00 & 2.36 & 0.904 & & & 2.10 & 2.29 & 0.236 & & & 2.22 \\
\hline TV Advertisements & 1.81 & 2.03 & 0.262 & & & 1.89 & 1.98 & 0.034 & & & 1.95 \\
\hline TV Programs & 2.25 & 2.39 & 0.124 & & & 2.23 & 2.40 & 0.170 & & & 2.34 \\
\hline Extension Newsletter & 2.52 & 3.46 & 8.636 & ** & .37 & 2.60 & 3.41 & 6.226 & * & .31 & 3.11 \\
\hline Extension Internet Site & 0.00 & 2.88 & 143.040 & ** & 1.75 & 0.73 & 2.76 & 37.538 & ** & .80 & 2.02 \\
\hline Electronic Mail & 0.88 & 2.78 & 32.802 & ** & .74 & 0.00 & 2.84 & 123.999 & ** & 1.44 & 2.02 \\
\hline Referrals - Friends & 2.24 & 2.94 & 4.413 & * & .29 & 2.20 & 2.94 & 4.885 & * & .31 & 2.66 \\
\hline Referrals - Public Agencies & 2.00 & 2.65 & 4.169 & * & .28 & 2.00 & 2.61 & 3.501 & & & 2.41 \\
\hline Referrals - Private Agencies & 1.90 & 2.51 & 3.325 & & & 1.89 & 2.49 & 2.976 & & & 2.29 \\
\hline
\end{tabular}

${ }^{*}=\mathrm{P}<.05,{ }^{* *}=\mathrm{P}<.01$

Rating Scale:

$0=$ No Access

$1=$ Greatly Dislike

$2=$ Dislike

$3=$ Preferred

$4=$ Greatly Preferred 


\section{Effects of Demographic Variables on Preferences}

Analyses of variance were performed to determine if there were significant

differences between preferences of methods and the following demographic variables: area, age, educational level, income, and gender. The results are shown in Tables 10 through 14. Significant difference in the respondents' preference of TV advertisements and programs existed based upon area (see Table 10). Urban residents responded with higher preferences for TV methods than did rural residents. Cohen's $f$ coefficients of .43 for TV advertisements and .45 for TV programs indicate a high effect size for differences in both methods.

Table 10

Comparison of Preferred Methods by Area $(\mathrm{N}=81)$

\begin{tabular}{|c|c|c|c|c|c|c|}
\hline Methods & $\begin{array}{c}\text { Rural } \\
M\end{array}$ & $\begin{array}{c}\text { Urban } \\
M\end{array}$ & $F$ & & Cohen's $f$ & $\begin{array}{l}\text { Overall } \\
\text { Mean } \\
\text { Rating }\end{array}$ \\
\hline Newspaper Advertisements & 2.58 & 2.47 & 0.111 & & & 2.48 \\
\hline Newspaper Articles & 2.76 & 2.77 & 0.000 & & & 2.72 \\
\hline Radio Advertisements & 2.07 & 2.43 & 0.895 & & & 2.20 \\
\hline Radio Programs & 1.93 & 2.61 & 3.562 & & & 2.22 \\
\hline TV Advertisements & 1.40 & 2.61 & 10.378 & ** & .43 & 1.95 \\
\hline TV Programs & 1.78 & 3.03 & 11.705 & ** & .45 & 2.34 \\
\hline Extension Newsletter & 3.03 & 3.32 & 0.828 & & & 3.11 \\
\hline Extension Internet Site & 2.00 & 2.12 & 0.077 & & & 2.02 \\
\hline Electronic Mail & 1.91 & 2.23 & 0.598 & & & 2.02 \\
\hline Referrals - Friends & 2.59 & 2.87 & 0.739 & & & 2.66 \\
\hline Referrals - Public Agencies & 2.37 & 2.54 & 0.295 & & & 2.41 \\
\hline Referrals - Private Agencies & 2.25 & 2.42 & 0.278 & & & 2.29 \\
\hline
\end{tabular}

${ }^{*}=\mathrm{P}<.05,{ }^{* *}=\mathrm{P}<.01$

Rating Scale:

$0=$ No Access

$1=$ Greatly Dislike

2= Dislike

$3=$ Preferred

4= Greatly Preferred 
As seen in Table 11, there are significant differences in preferences for newspaper advertisements, newspaper articles, radio advertisements, radio programs, TV advertisements, electronic mail, and referrals by public and private agencies based upon age. All eight methods show a large effect size with Cohen's $f$ coefficients of .40 or larger. A Scheffe's Post Hoc analysis was performed to determine the relative difference between age groups for the indicated methods. The 70+ age group rated newspaper advertisements and articles lower than the 60-69, 50-59, and 40-49 age groups, as well as ranking radio advertisements, referrals from public agencies, and referrals from private agencies lower than the 50-59 age group. The $70+$ age group also ranked referrals from private agencies lower than the 40-49 age group.

There seems to be no significant differences in preferred methods by education level. These data can be seen in Table 12 .

There were significant differences in preferences of newspaper articles, extension newsletters, referrals from friends and private and public agencies based upon income level. These data are presented in Table 13. From the Scheffe's post hoc performed on the data, it was found that the $\$ 20,000$ to $\$ 39,999$ income group ranked referrals from friends higher than did the $\$ 0$ to $\$ 19.999$ income group. 
Table 11

Comparison of Preferred Methods by Age $(N=81)$

\begin{tabular}{|c|c|c|c|c|c|c|c|c|c|}
\hline Methods & $\frac{30-39}{M}$ & $\frac{40-49}{M}$ & $\frac{50-59}{M}$ & $\frac{60-69}{M}$ & $\frac{70+}{M}$ & $F$ & & Cohen's $f$ & $\begin{array}{c}\text { Overall } \\
\text { Mean } \\
\text { Rating }\end{array}$ \\
\hline Newspaper Advertisements $^{1}$ & 3.00 & 2.85 & 2.86 & 2.45 & 0.50 & 7.262 & ** & .71 & 2.48 \\
\hline Newspaper Articles ${ }^{2}$ & 3.00 & 3.15 & 3.03 & 2.82 & 0.89 & 6.620 & ** & .66 & 2.72 \\
\hline Radio Advertisements ${ }^{3}$ & 2.00 & 2.45 & 2.54 & 2.30 & 0.63 & 3.173 & * & .48 & 2.20 \\
\hline Radio Programs & 2.00 & 2.50 & 2.42 & 2.45 & 0.71 & 2.634 & * & .45 & 2.22 \\
\hline TV Advertisements & 1.50 & 1.54 & 2.46 & 2.18 & 0.57 & 2.723 & * & .45 & 1.95 \\
\hline TV Programs & 1.50 & 2.00 & 2.75 & 2.45 & 1.50 & 1.400 & & & 2.34 \\
\hline Extension Newsletter & 3.50 & 3.38 & 3.24 & 3.20 & 1.71 & 2.353 & & & 3.11 \\
\hline Extension Internet Site & 2.00 & 2.08 & 2.52 & 1.54 & 1.00 & 1.749 & & & 2.02 \\
\hline Electronic Mail & 2.50 & 2.14 & 2.54 & 1.00 & 1.13 & 2.774 & * & .44 & 2.02 \\
\hline Referrals - Friends & 2.50 & 3.17 & 2.83 & 2.50 & 1.63 & 2.303 & & & 2.66 \\
\hline Referrals - Public Agencies ${ }^{4}$ & 3.50 & 2.50 & 2.63 & 2.56 & 1.00 & 4.062 & 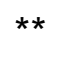 & .58 & 2.41 \\
\hline Referrals - Private Agencies ${ }^{5}$ & 3.50 & 2.67 & 2.50 & 2.10 & 0.86 & 4.190 & ** & .58 & 2.29 \\
\hline
\end{tabular}

${ }^{*}=\mathrm{P}<.05,{ }^{* *}=\mathrm{P}<.01$

Rating Scale:

$0=$ No Access

$1=$ Greatly Dislike

2= Dislike

$3=$ Preferred

4= Greatly Preferred

\section{Scheffe Post Hoc Comparisons}

$\begin{array}{ll}170+<69-69,70+<50-59,70+<40-49 & 370+<50-59 \\ 270+<69-69,70+<50-59,70+<40-49 & 470+<50-59\end{array} \quad{ }^{4} 70+<50-59,70+<40-49$ 
Table 12

Comparison of Preferred Methods by Highest Education Level ( $N=81)$

\begin{tabular}{|c|c|c|c|c|c|c|c|}
\hline Methods & $\begin{array}{c}\text { High } \\
\text { school } \\
\text { Diploma } \\
\text { or GED } \\
M\end{array}$ & $\begin{array}{c}\begin{array}{c}2-y r \\
\text { Degree } \\
\text { or Tech } \\
\text { School }\end{array} \\
M\end{array}$ & $\begin{array}{l}\text { Bachelors } \\
\text { Degree }\end{array}$ & $\begin{array}{c}\text { Graduate } \\
\text { Degree }\end{array}$ & $F$ & $\begin{array}{c}\text { Cohen's } \\
f f\end{array}$ & $\begin{array}{l}\text { Overal } \\
\text { Mean } \\
\text { Rating }\end{array}$ \\
\hline Newspaper Advertisements & 2.72 & 2.33 & 2.25 & 2.50 & 0.366 & & 2.48 \\
\hline Newspaper Articles & 2.79 & 2.60 & 2.63 & 2.74 & 0.064 & & 2.72 \\
\hline Radio Advertisements & 2.31 & 2.10 & 2.43 & 2.00 & 0.255 & & 2.20 \\
\hline Radio Programs & 2.38 & 1.67 & 2.53 & 2.12 & 0.789 & & 2.22 \\
\hline TV Advertisements & 2.38 & 1.40 & 1.88 & 1.94 & 0.814 & & 1.95 \\
\hline TV Programs & 2.56 & 2.00 & 2.38 & 2.29 & 0.263 & & 2.34 \\
\hline Extension Newsletter & 3.29 & 2.22 & 3.50 & 3.00 & 1.999 & & 3.11 \\
\hline Extension Internet Site & 2.33 & 0.90 & 2.06 & 2.27 & 2.135 & & 2.02 \\
\hline Electronic Mail & 1.89 & 1.00 & 2.19 & 2.39 & 1.739 & & 2.02 \\
\hline Referrals - Friends & 2.62 & 2.60 & 2.73 & 2.67 & 0.030 & & 2.66 \\
\hline Referrals - Public Agencies & 2.64 & 2.60 & 2.00 & 2.50 & 0.974 & & 2.41 \\
\hline Referrals - Private Agencies & 2.64 & 2.20 & 2.13 & 2.20 & 0.513 & & 2.29 \\
\hline \multicolumn{8}{|c|}{ Significant differences not found at the $\mathrm{P}<.05$ level. } \\
\hline $\begin{array}{l}\text { Rating Scale: } \\
0=\text { No Access } \\
1=\text { Greatly Dislike } \\
2=\text { Dislike } \\
3=\text { Preferred } \\
4=\text { Greatly Preferred }\end{array}$ & & & & & & & \\
\hline
\end{tabular}


Table 13

Comparison of Preferred Methods by Income ( $N=81)$

\begin{tabular}{|c|c|c|c|c|c|c|c|c|c|c|}
\hline \multirow[b]{2}{*}{ Methods } & 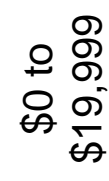 & 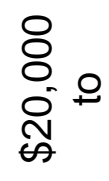 & 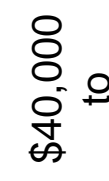 & $\begin{array}{l}8 \\
8 \\
8 \\
8 \\
6\end{array}$ & $\begin{array}{l}8 \\
8 \\
0 \\
\infty \\
0 \\
0\end{array}$ & 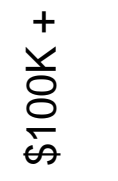 & \multirow[b]{2}{*}{$F$} & & \multirow[b]{2}{*}{ Cohen's $f$} & \multirow{2}{*}{$\begin{array}{c}\text { Overall } \\
\text { Mean } \\
\text { Rating }\end{array}$} \\
\hline & $M$ & $M$ & $M$ & $M$ & $M$ & $M$ & & & & \\
\hline Newspaper Advertisements & 1.40 & 2.50 & 2.55 & 2.70 & 3.00 & 3.65 & 2.247 & & & 2.48 \\
\hline Newspaper Articles & 1.40 & 2.63 & 2.85 & 3.10 & 3.00 & 3.67 & 2.713 & * & .53 & 2.72 \\
\hline Radio Advertisements & 0.00 & 2.69 & 2.67 & 2.40 & 3.00 & 1.89 & 2.292 & & & 2.20 \\
\hline Radio Programs & 0.75 & 2.67 & 2.36 & 2.44 & 3.50 & 1.89 & 1.783 & & & 2.22 \\
\hline TV Advertisements & 0.80 & 1.86 & 2.25 & 2.20 & 3.00 & 2.22 & 0.783 & & & 1.95 \\
\hline TV Programs & 0.80 & 2.29 & 2.45 & 2.70 & 3.50 & 2.40 & 1.280 & & & 2.34 \\
\hline Extension Newsletter & 1.40 & 3.36 & 2.80 & 3.56 & 3.00 & 3.70 & 3.174 & * & .57 & 3.11 \\
\hline Extension Internet Site & 1.00 & 1.77 & 2.21 & 2.10 & 0.00 & 2.40 & 0.814 & & & 2.02 \\
\hline Electronic Mail & 0.25 & 2.07 & 2.31 & 2.20 & 0.00 & 2.33 & 1.597 & & & 2.02 \\
\hline Referrals - Friends ${ }^{1}$ & 1.00 & 3.08 & 2.90 & 2.56 & 3.50 & 3.00 & 3.033 & * & .62 & 2.66 \\
\hline Referrals - Public Agencies & 0.75 & 2.69 & 2.33 & 2.56 & 4.00 & 3.13 & 4.548 & ** & .74 & 2.41 \\
\hline Referrals - Private Agencies & 0.75 & 2.46 & 2.17 & 2.40 & 4.00 & 3.13 & 3.281 & * & .62 & 2.29 \\
\hline
\end{tabular}

${ }^{*}=\mathrm{P}<.05,{ }^{* *}=\mathrm{P}<.01$

Rating Scale:

$0=$ No Access

$1=$ Greatly Dislike

2= Dislike

$3=$ Preferred

$4=$ Greatly Preferred

\section{Scheffe Post Hoc Comparisons}

${ }^{1} \$ 20,000$ to $\$ 39,999>\$ 0$ to $\$ 19,999$ 
There seems to no difference between males and females as to their preferences of methods for receiving Extension information as shown in Table 14.

Table 14

Comparison of Preferred Methods by Gender ( $N=81)$

\begin{tabular}{|c|c|c|c|c|c|}
\hline Methods & $\begin{array}{r}\text { Male } \\
M\end{array}$ & $\frac{\text { Female }}{M}$ & $F$ & Cohen's $f$ & $\begin{array}{c}\text { Overall } \\
\text { Mean Rating }\end{array}$ \\
\hline Newspaper Advertisements & 2.41 & 2.57 & 0.169 & & 2.48 \\
\hline Newspaper Articles & 2.50 & 2.85 & 0.864 & & 2.72 \\
\hline Radio Advertisements & 2.13 & 2.28 & 0.110 & & 2.20 \\
\hline Radio Programs & 2.43 & 2.21 & 0.262 & & 2.22 \\
\hline TV Advertisements & 2.14 & 1.93 & 0.197 & & 1.95 \\
\hline TV Programs & 2.63 & 2.29 & 0.550 & & 2.34 \\
\hline Extension Newsletter & 3.53 & 3.04 & 1.707 & & 3.11 \\
\hline Extension Internet Site & 1.86 & 2.11 & 0.276 & & 2.02 \\
\hline Electronic Mail & 1.67 & 2.17 & 1.177 & & 2.02 \\
\hline Referrals - Friends & 3.00 & 2.61 & 1.154 & & 2.66 \\
\hline Referrals - Public Agencies & 2.77 & 2.35 & 1.387 & & 2.41 \\
\hline Referrals - Private Agencies & 2.36 & 2.33 & 0.007 & & 2.29 \\
\hline
\end{tabular}

Significant differences not found at the $\mathrm{P}<.05$ level.

Rating Scale:

$0=$ No Access

$1=$ Greatly Dislike

$2=$ Dislike

$3=$ Preferred

4= Greatly Preferred 


\section{CHAPTER V}

\section{SUMMARY, CONCLUSIONS, AND RECOMMENDATIONS}

\section{Purpose and Objectives}

The major purpose of this study was to provide information to Extension agents and administrators regarding effectiveness of the various methods of advertising and marketing that may help them choose methods that will encourage participation in Extension programs.

The primary objective of this study was to evaluate the effectiveness of the various methods of promoting WVU-ES programs on the experiences of current adult Master Gardeners in West Virginia.

\section{$\underline{\text { Research Questions }}$}

The research questions that directed this study were:

1. How did Master Gardeners first become aware of Extension programs?

2. Which marketing methods are most effective at promoting awareness of other Extension programs among Master Gardeners?

3. Does participation in the Master Gardener Program promote interest in other Extension Programs?

4. What are the preferences of Master Gardeners in receiving Extension information?

5. Does the availability of Internet related communication channels affect the preferences of certain marketing methods? 
6. What is the relationship between selected demographic variables; rural/ suburban/ urban, age, education, gender and economic status, and preferences of marketing methods?

Data were analyzed at West Virginia University using the Statistical Package for the Social Sciences for Windows (SPSS). Data were analyzed using frequencies, percentages, and means for descriptive analysis and ANOVA and Cohen's $f$ coefficients for comparisons.

\section{Demographics}

The target population for this study consisted of all 819 members of the Master Gardeners Program in West Virginia as listed in the 2001 State Master Gardener Directory. The accessible population consisted of a random sample of 130 members. There were 81 respondents to the survey resulting in a response rate of $62.3 \%$. The participants were asked their area (rural or urban), age range, education level, income, and gender.

About half of the respondents live in rural areas (54\%) and half in urban or suburban areas (46\%). Nearly $80 \%$ are over 50 years of age. More than half have a college degree, and most make between $\$ 20,000$ to $\$ 60,000$ annually. Approximately three fourths of Master Gardeners are female (73\%).

$\underline{\text { Conclusion }}$

- Master Gardeners are from both rural and urban communities, are older, well educated, earn high incomes and are mostly female. 


\section{Awareness of Extension Programming}

A high percentage (94.9\%) of Master Gardeners are aware of the $4-\mathrm{H}$ program, $92.6 \%$ are aware of agricultural programs, $61.7 \%$ are aware of CEOS, and $57.1 \%$ are aware of Extension community development programs This is higher than the national awareness levels for all potential clientele. Warner, Christenson, Dilman, and Salant (1996) report that $69 \%$ of Americans are aware of $4-\mathrm{H}, 50 \%$ are aware of agricultural programs, $51 \%$ are aware of home economics programs like Community Education and Outreach Service (CEOS), and 38\% are aware of community development.

\section{$\underline{\text { Conclusion }}$}

- Nearly all Master Gardeners are aware of the 4-H program and agricultural programs. Fewer are aware of CEOS and community development programs. Methods - First Awareness of the Master Gardener Program

West Virginia Master Gardeners were asked to indicate the method by which they first became aware of the Master Gardener program and whether Master Gardeners was their first experience with Extension. Referrals from friends, relatives, and peers had the highest frequency for first awareness of the Master Gardener program, with $38.3 \%$ of the respondents. Newspaper articles were second in effectiveness with $28.4 \%$. Of the respondents, approximately half had no previous experience with Extension.

\section{$\underline{\text { Conclusions }}$}

- Master Gardeners first became aware of the Master Gardener program via referrals from friends, relatives, and peers or via newspaper articles. 
- Referrals from friends and newspaper articles represented first awareness of Extension for roughly half of Master Gardeners.

\section{Methods - First Awareness of Other Extension Programs}

Master Gardeners were asked to indicate the methods by which they found out about other Extension programs, i.e. agricultural programs, CEOS and home economics programs, community development programs, and 4-H. Referrals from friends, relatives, and peers was the most frequent method of awareness, and participating in other Extension programs was second. Newspaper articles were the third most often indicated. While referrals from friends outranked participation in other programs overall, in both agricultural programs and community development participation in other programs was the most indicated by the respondents.

Roughly half of the Master Gardeners indicated their first experience with Extension was not with the Master Gardener program. Of that group, 38.2\% indicated that $4-\mathrm{H}$ was their first experience, $29.4 \%$ indicated agricultural programs, $23.5 \%$ said CEOS was their first experience, and only, $8.8 \%$ indicated community development. $\underline{\text { Conclusions }}$

- Master Gardeners first became aware of other Extension programs via referrals from friends, relatives, and peers, via participation in other Extension programs, or via newspaper articles.

- Half of the Master Gardeners found out about other Extension programs while participating in Master Gardeners.

- People join Master Gardeners and then become aware of other programs offered by Extension. 
- Referrals from friends and participation in other programs are complementary methods.

\section{Encouragement to Participate in Other Extension Programs}

Slightly less than half (44.9\%) of the respondents said that participation in Master Gardeners encouraged participation in other programs.

\section{Conclusion}

- Participation in Master Gardeners encourages participation in other Extension programs.

\section{Preferences of Methods}

The preferred method of receiving Extension information is the Extension Newsletter, with $54.5 \%$ ranking it as greatly preferred and $28.8 \%$ ranking it as preferred. Newspaper articles received $44.6 \%$ responses in the preferred category and $30.8 \%$ in the greatly preferred category making it the second most preferred method and the most preferred mass media method. Newspaper advertisements were third with $41.9 \%$ indicating preference and $22.6 \%$ indicating great preference. About half of Master Gardeners ranked referrals in the preferred category. While no particular method received a large percentage of respondents indicating that they disliked or greatly disliked that method, about a third indicated no access to electronic communications (Internet and e-mail) and television methods. Few indicated they had no access to the Extension newsletter.

\section{$\underline{\text { Conclusions }}$}

- Extension newsletters are greatly preferred over other methods of receiving Extension information and are more likely to be received due to access. 
- Newspaper articles and advertisements are the second most preferred method.

- Print methods are preferred over more fleeting methods such as radio, TV, and word of mouth.

- Lack of access to Internet, e-mail, and television programming hinders the communication of Extension information by those channels.

Preferences of Methods by Internet and E-mail Access

Approximately three-fourths of Master Gardeners indicated they never access the WVU-ES website, and 30\% responded that they never read e-mail. Those with access prefer newspaper articles, extension newsletters, and referrals from friends over Internet and e-mail. They also have a higher preference for receiving Extension information by electronic means than Master Gardeners with no access to Internet and e-mail.

\section{$\underline{\text { Conclusions }}$}

- Master Gardeners with electronic communications read their e-mail more often and regularly than they access the WVU-ES website.

- Master Gardeners with computer access still prefer newspaper articles, newsletters, and friends' referrals over electronic means.

- Master Gardeners with Internet and e-mail access prefer those methods when compared with Master Gardeners with no Internet or e-mail access. Effects of Demographics on Preferences of Methods

Analyses of variance were performed to determine if there were significant differences between preferences of methods and area, age, education level, income, and gender. There were no significant differences for education level and gender. 
However, there were significant differences in preference of TV advertisements and TV programs based upon area with urban residents preferring TV methods more highly than rural residents. There were also significant differences between eight of the methods and age. Post Hoc analysis showed that the 70+ age group preferred newspapers, radio advertisements, and referrals from public and private agencies less than did other age groups. Respondents indicated significant differences for newspaper articles, Extension newsletters, and referrals based upon income. Data indicated that the $\$ 0$ to $\$ 19,999$ income group rated newspaper articles, newsletters, and referrals from friends significantly lower than other groups.

$\underline{\text { Conclusions }}$

- Urban residents prefer TV methods of communication more than do rural residents.

- The 70+ age group prefers to receive Extension information via newspaper, radio, and referrals from public and private agencies.

- Low income clientele prefer newspaper articles, newsletters, and friends' referrals less than do wealthier clientele.

$\underline{\text { Recommendations for Extension Professionals }}$

In order to help them choose methods that will encourage participation in Extension programs, the following recommendations are made to WVU Extension professionals based on the review of the literature, the researcher's experience, and the results of this study:

- This study should be replicated in its complete or modified form to Extension professionals nationally or locally to determine if the findings differ significantly from those of this study. 
- Extension professionals should develop excellent article writing skills that will both entertain and inform potential clientele while persuading them to participate in Extension programs.

- Mass media methods that facilitate word of mouth methods should be chosen. Print methods allow for people to share the printed information with others.

- Make sure that all mailing lists for newsletters are complete, accurate, and up to date.

- Send an electronic newsletter to those clientele who have e-mail.

- Develop listserves for clientele groups for efficient e-mailing of pertinent information.

- To encourage more people to access the WVU-ES website, the web address should be included with every newspaper article and advertisement.

- Utilize radio and TV programs as opposed to advertisements in areas where local stations are available.

- Develop more high visibility programs like Master Gardeners. 


\section{REFERENCES}

Adkins, R. (1981). Motherhood, apple pie, state legislators, and Extension. Journal of Extension , 3, 7 -11.

American Psychological Association. (2002). Publication Manual of the American Psychological Association ( $5^{\text {th }}$ ed.). Washington, D.C.: American Psychological Association.

Ary, .D., Jacobs, L. C., \& Razavieh, A. (1990). Introduction to Research in Education. Orlando, FL: Harcourt Brace.

Cohen, J. (1988). Statistical Power Analysis for the Behavioral Sciences (2 ${ }^{\text {nd }}$ ed.). Hillsdale, NJ: Lawrence Earlbaum Associates.

Cooperative State Research, Education, and Extension Service. (2001) About CSREES. Retrieved October 15, 2001 from CSREES w Web site: http://www.reeusda.gov/1700/csreesa2.html\#about.

Culp, K. (1997). Major customer turnoffs: Implications for Extension. Journal of Extension, 3. Retrieved April 7, 2001 from: http://www.joe.org/joe/1997june/iw3.html.

Dennis, S. A., Lee, T. R., \& Jenson, G. O. (1995). Using community access cable in an Extension parenting education program. Journal of Extension, 2. Retrieved from: http://www.joe.org/joe/1995april/a5.html.

Dillman, D. A. (1978). Mail and telephone surveys. New York: John Wiley and Sons.

Hogan, M. (1994). Effective public relations in Extension. Journal of Extension, 3. Retrieved from: http://www.joe.org/joe/1994october/a1.html.

Jenkins, D. (1993). Survival depends on reaching influential audiences. Journal of Extension, 3. Retrieved from: http://www.joe.org/joe/1993fall/tp3.html.

Lionberger, H. F. \& Gwin, P. H. (1982). Communication Strategies: A Guide for Agricultural Change Agents. Danville, IL: Interstate.

Meadowbrook, A \& Fletcher, R. L. (1988). It's worth the effort. Journal of Extension, 3. Retrieved from: http://www.joe.org/joe/1988fall/ent.html.

Najafi, Y. (1975). Sources of agricultural information and their ratings as perceived by selected farmers in West Virginia. (Master's Thesis), West Virginia University, Morgantown, WV. 
O'Neill, B. (1987). Extension makes the news. Journal of Extension, 3. Retrieved from: http://www.joe.org/joe/1987fall/iw2.html.

Warner, P., Christenson, J., Dillman, D., \& Salant, P. (1996). Public perception of Extension. Journal of Extension, 4. Retrieved from: http://www.joe.org/joe/1996august/a1.html.

Weerakkody, P. W. (1986). Major problems affecting the dissemination of agricultural information to farmers/ ranchers by Extension agents as perceived by county agricultural Extension agents. (Master's Thesis), West Virginia University, Morgantown, WV.

West Virginia University Extension Service. (2001). Master Gardener Program. Retrieved October 15, 2001 from WVU-ES Web site: http://www.wvu.edu/ agexten/hortcult/master/index.html.

West Virginia University Extension Service. (2000). WVU-ES: Who it is and what it does. Retrieved October 15, 2001 from WVU-ES Web site: http://www.evu.edu/ exten/about/whowhat.htm. 


\section{APPENDICES}




\section{APPENDIX A:}

Survey Instrument 


\section{Evaluation of Marketing Methods Used to Promote Extension Programs as Perceived by Master Gardeners in West Virginia}

To the best of your knowledge or recollection, please complete this survey following directions given for each question.

1) How did you first become aware of the Master Gardeners program? (Check ONE)

( ) Newspaper Advertisement

( ) Newspaper Article

( ) Radio Advertisement

( ) Radio Program

( ) TV Advertisement

( ) TV Program

( ) Extension Newsletter

( ) Extension Internet Site

( ) From a friend, relative or peer

( ) From another public agency (such as the Farm Service Agency, county commission, health department, etc.)

( ) From private agencies or businesses (such as Farm Bureau or local agricultural related businesses)

( ) While participating in other Extension programs

( ) Other

2) Have you ever heard of WVU Extension agricultural programs? (Check ONE)
( ) Yes
( ) No

If yes, how did you first hear of them? (Check ONE)

( ) Newspaper Advertisement

( ) Newspaper Article

( ) Radio Advertisement

( ) Radio Program

( ) TV Advertisement

( ) TV Program

( ) Extension Newsletter

( ) Extension Internet Site

( ) From a friend, relative or peer

( ) From another public agency (such as the FSA, county commission, health department, etc.)

( ) From private agencies or businesses (such as Farm Bureau or local agricultural related businesses)

( ) While participating in other Extension programs

( ) Other 
3) Have you ever heard of WVU Extension Community Education and Outreach Clubs (CEOS) and other home economics programs? (Check ONE)
( ) Yes
( ) No

If yes, how did you first hear of them? (Check ONE)

( ) Newspaper Advertisement

( ) Newspaper Article

( ) Radio Advertisement

( ) Radio Program

( ) TV Advertisement

( ) TV Program

( ) Extension Newsletter

( ) Extension Internet Site

( ) From a friend, relative or peer

( ) From another public agency (such as the Farm Service Agency, county commission, health department, etc.)

( ) From private agencies or businesses (such as Farm Bureau or local agricultural related businesses)

( ) While participating in other Extension programs

( ) Other

4) Have you ever heard of WVU Extension community and economic development programs? (Check ONE)
( ) Yes
( ) No

If yes, how did you first hear of them? (Check ONE)

( ) Newspaper Advertisement

( ) Newspaper Article

( ) Radio Advertisement

( ) Radio Program

( ) TV Advertisement

( ) TV Program

( ) Extension Newsletter

( ) Extension Internet Site

( ) From a friend, relative or peer

( ) From another public agency (such as the Farm Service Agency, county commission, health department, etc.)

( ) From private agencies or businesses (such as Farm Bureau or local agricultural related businesses)

( ) While participating in other Extension programs

( ) Other 
5) Have you ever heard of WVU Extension 4-H and youth development programs? (Check ONE)

( ) Yes ( ) No

If yes, how did you first hear of them? (Check ONE)

( ) Newspaper Advertisement

( ) Newspaper Article

( ) Radio Advertisement

( ) Radio Program

( ) TV Advertisement

( ) TV Program

( ) Extension Newsletter

( ) Extension Internet Site

( ) From a friend, relative or peer

( ) From another public agency (such as the Farm Service Agency, county commission, health department, etc.)

( ) From private agencies or businesses (such as Farm Bureau or local agricultural related businesses)

( ) While participating in other Extension programs

( ) Other

6) Is participation in the Master Gardeners program your first experience with the WVU Extension Service?

(Check ONE)

( ) Yes ( ) No

If not, which of the following groups would include your first experience with Extension?

(Check ONE)

( ) Agricultural programs

( ) CEOS and other home economics programs

( ) Community and economic development programs

( ) 4-H and youth development programs

7) Has your participation in the Master Gardeners program encouraged your participation in other Extension programs? (Check ONE)

( ) Yes ( ) No

8) How often do you access your state or local Extension Service's website each month? (Check ONE)

( ) Never

( ) 1 to 3 times

( ) 7 to 9 times

( ) 4 to 6 times

( ) More than 9 times

9) How often do you read your E-mail each week? (Check ONE)

( ) Never

( ) 7 to 9 times

( ) 1 to 3 times

( ) More than 9 times

( ) 4 to 6 times 
10) If you would like to receive further information on Extension programs, please rate (by circling) your preference of each method as a channel for receiving this information $(4=$ Greatly prefer this method; $3=$ Prefer this Method; 2 = Dislike this method; $1=$ Greatly dislike this method). If you do not have access to a specific communication channel (i.e. no computer with which to receive the Internet or Email) then please circle the $\mathbf{0}$ in the No Access column.

\begin{tabular}{|c|c|c|c|c|c|}
\hline & \\
\hline & 㓂总 & D. & 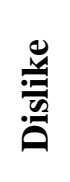 & 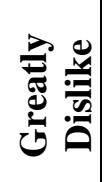 & 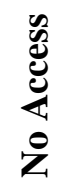 \\
\hline Newspaper Advertisements & 4 & 3 & 2 & 1 & 0 \\
\hline Newspaper Articles & 4 & 3 & 2 & 1 & 0 \\
\hline Radio Advertisements & 4 & 3 & 2 & 1 & 0 \\
\hline Radio Programs & 4 & 3 & 2 & 1 & 0 \\
\hline TV Advertisements & 4 & 3 & 2 & 1 & 0 \\
\hline TV Programs & 4 & 3 & 2 & 1 & 0 \\
\hline Extension Newsletter & 4 & 3 & 2 & 1 & 0 \\
\hline Extension Internet Site & 4 & 3 & 2 & 1 & 0 \\
\hline Electronic Mail & 4 & 3 & 2 & 1 & 0 \\
\hline Referrals from friends, relatives and peers & 4 & 3 & 2 & 1 & 0 \\
\hline Referrals from other public agencies & 4 & 3 & 2 & 1 & 0 \\
\hline Referrals from private agencies and businesses & 4 & 3 & 2 & 1 & 0 \\
\hline
\end{tabular}

11) Where do you live? (Check ONE) limits)

( ) Rural Area (Towns with populations less than 2500, unincorporated towns, out of town

( ) Urban or Suburban Area (Cities and towns with populations of more than 2500)

12) What age group are you in? (Check ONE)
( ) 20 to 29
( ) 50 to 59
( ) 30 to 39
( ) 60 to 69
( ) 40 to 49
( ) $70+$

13) What is your highest educational level? (Check ONE)
( ) Less than High School
( ) Bachelor's Degree
( ) High School Diploma or GED
( ) Graduate Degree
( ) 2 Year Degree or Technical School

14) What is your income level? (Check ONE)
( ) $\$ 0$ to $\$ 19,999$
( ) $\$ 60,000$ to $\$ 79,999$
( ) $\$ 20,000$ to $\$ 39,999$
( ) $\$ 80,000$ to $\$ 99,999$
( ) $\$ 40,000$ to $\$ 59,999$
( ) $\$ 100,000+$

15) What is your gender? (Check ONE)
( ) Male
( ) Female 
APPENDIX B:

Letter to Selected Master Gardeners 
February 25, 2002

MEMORANDUM

TO: $\quad$ Selected West Virginia Master Gardeners

FROM: $\quad$ Tiffany Dale Rexroad

Graduate Student

Agricultural Education

Layle D. Lawrence

Professor and Chair

Agricultural and Environmental Education

We are conducting a study on the methods of promoting WVU Extension programs as perceived by West Virginia Master Gardeners. We would like to know which methods you are exposed to and which methods you prefer. Results of this study may be used to help your county agents chose promotional methods that reach a greater portion of the population. The research will be used to prepare a thesis to partially fulfill the requirements for a Master's of Science Degree in Agricultural Education.

Although your participation in this study is voluntary, we are asking you to take a few minutes of your time to fill out the enclosed survey. Please answer every question you feel comfortable answering. Be assured your answers will remain as confidential as legally possible. You will notice a code in the bottom right hand corner. This code will be used only to identify non-respondents for follow-up and will be destroyed before the data are analyzed.

When you have completed the survey, please return it using the enclosed selfaddressed stamped envelope by March 18, 2002. Your participation and assistance is greatly appreciated. 


\section{APPENDIX C:}

Follow Up Letter to Master Gardeners 
February 25, 2002

MEMORANDUM

TO: $\quad$ Selected West Virginia Master Gardeners

FROM: $\quad$ Tiffany Dale Rexroad

Graduate Student

Agricultural Education

Layle D. Lawrence

Professor and Chair

Agricultural and Environmental Education

We recently mailed you a survey concerning the thesis study we are conducting on methods of promoting Extension as perceived by Master Gardeners.

As of yet, we have not received your response. If you have responded and have merely crossed in the mail, let us thank you. If not, please take a minute to fill out the enclosed survey. Your participation is completely voluntary, and we realize you do not have a lot of extra time. We ask you to keep in mind that you would be helping me reach a goal of obtaining my Master's Degree this semester. Your assistance would be greatly appreciated.

Enclosed is a self-addressed stamped envelope for your convenience. If we might have your response by April 1, 2002, we would be greatly appreciative. Please feel free to fax the information to us at (304) 293-3752.

Thank you for your cooperation. 
VITA

Tiffany Dale Rexroad

1997

Associate of Applied Science

Agricultural Management

Garrett Community College

McHenry, MD

1997

Two-year Certificate

Agricultural Management

University of Maryland

Institute of Applied Agriculture

College Park, MD

1997-1999

Extension Intern

Preston County Office

West Virginia University Extension Service Kingwood, WV

1999

Bachelor of Science in Agriculture Agricultural and Environmental Education West Virginia University

Morgantown, WV

2002

Master of Science

Agricultural Education

West Virginia University

Morgantown, WV 